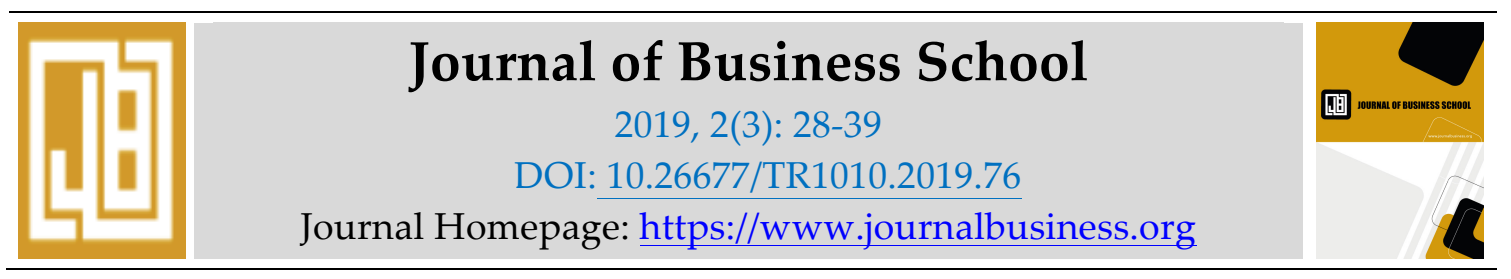

\title{
The Role of Institutions in Affecting the Course of International Trade in The Neighboring Countries of Ghana
}

\section{Ignatius Abasimi,}

School of Economics, Northeast Normal University, Changchun, Jilin, China. abasimiignatus@gmail.com

\section{Xuan Li,}

School of Economics, Northeast Normal University, Changchun, Jilin, China.

\section{Agus Salim,}

School of Economics, Northeast Normal University, Changchun, Jilin, China.

\section{Muhammad Imran Khan}

School of Economics, Northeast Normal University, Changchun, Jilin, China.

\begin{abstract}
A recent dilemma and a discourse among international trade economist is whether political and economic institutions really have an impact in promoting the course of international trade in contemporary epochs. Among this relationship, does these institutions helps developing countries to achieve economic salvation? This study empirically investigates the role of institutions in affecting the course of international trade in the neighboring countries of Ghana (Togo, Burkina Faso, and Cote d'Ivoire). The study uses panel data from 1995-2017. The fixed effect model was employed for the econometric analysis. The output from the model revealed that exchange rate, freedom from corruption, property rights and trade freedom are statistically significant in explaining the role of institutions in promoting the course of international trade in the neighboring countries of Ghana.
\end{abstract}

Keywords: International trade, institutions, mixed effect, neighboring, Ghana.

\section{Introduction}

According to an American economist, Douglass Cecil North (1991), an institution is a "humanly devised constraints that structure political, economic and social interactions". This implies that a well-structured political and economic characteristic are fundamental to trade facilitations and economic progress.

Most economic growth theories have led emphasis on key economic development indicators that pathed the way to most resilient and strong economics in contemporary times, such as UK, USA, China, Germany, Japan etc, The Solow economic growth model for instance, has outlined that, a well mixer of technology and labor-augmenting technological progress are logic key 
instruments to not only reaching the steady state of developing economies but also as a means of economic advancement (Robert Solow, 1956). This implies that a well-structured institution leads to economic development, which in turn improves institutional quality. The direction of causation however differs between the developed and developing economies. In developed countries, resilient institutional quality foments economic development, whereas the reverse is rather true in developing countries (Law et al., 2013).

In the last one and half centuries, wages in the less developed countries have fallen far behind those in the developed countries, both in absolute, relative and proportionate terms, between 1870 to 1990, the ratio of per capita incomes between the developed and the developing countries increased by roughly a factor of five and that the disparities in incomes between the richest country and all others has increased by an order of magnitude (Lant Pritchett, 1997). In 1870, these set of countries (developed and developing) Has been different from each other with "high income OECD" countries being identified as the European countries and their offshoots not leaving Japan out. The growth rate of these countries has been remarkably by historical standards and has left a wide gap among the less develop lower income countries to catch up. Apparently, its seems in any case that this growth sample started changing from 1980, after that few of the fastest developing countries on the planet have equally been low-income countries. Consider isolates economies along with wage quintile in the light of 1980 for per head GDP, and setups consequent populace weighted growth rates (Najaf Ali, 2018). This may probably or largely attribute to the different institutional setups in those economists.

Lant Pritchett (1997), further noted that between 1870-1989 the annual GDP per capita average growth rate of most industrialized economists were awkwardly lower than their offshoots countries. As of 1870-1960, USA, Great Britain, Germany and Japan annual GDP per capita were $1.7 \%, 1.08 \%, 1.66 \%$ and $1.86 \%$ per annum respectively. Lant Pritchett strongly believed that convergence will make poorer nations to growth faster and probably overtake richer nations. These predictions are being materialized with the recent economic advancement in the Asian continent, countries such as China, Hongkong, India, Vietnam and others which were considered heavenly poor countries in the 1980s are now growing at galloping pace. These magnificent economic transformations have increased the world economic output considerably, this may be associated with two basic reasons; firstly, international trade has strengthened between and amongst their trading patterners, these economists have realized the vital role of trade and perhaps expanded their economist to the rest of the world. This economic circumvention has led to a considerably rise in their international inflows. Secondly, the role of institutions has also exacted some kind of efficiency in income and assets distributions amongst the business economic agents. A stable, trustworthy and workable institutions significantly affect a country economic progress positively.

According to the World Bank 2018 Africa report, most of 2018's top economy performers are non-commodity intensive economies, and Africa has six of the world's ten fastest growing economies. The list is led by Ghana $(8.3 \%)$, which is boosted by oil \& gas expansion, Ethiopia $(8.2 \%)$, Côte d'Ivoire (7.2\%), Djibouti (7\%), Senegal (6.9\%) and Tanzania (6.8\%).

A couple of studies has been carried out on the role of institutions in economic development and integrations, some has found a bi-directional cause and effects relationships between institutions, economic growth and development (see Bates et al., 2013; Chong and Calderon 2000). A more recent studies of Ignatius Abasimi et al 2018 and Najaf Ali, 2018 reveals quite a robust and perverse effects of institutions on international trade. Most of these studies however focused on only the role of institutions in productivity growth, investment and economic growth to the neglect of the impact of these institutions on international trade (see Easterly et al., 2004; Bates et al., 2013, Robinson, 2001; Acemoglu et al., 2001;). Nevertheless, the 
aforementioned studies engrossed and limited their research to a single and distinct countries. Ergo, the none effectuating economic growth in most and almost some West African countries, including Togo Burkina Faso and Cote d'Ivoire, is largely due to or contributing to the weak institutional quality in promoting international trade and economic development.

Due to this fallibility and deficiency in the existing literature, this study seeks to fill the research gap and contribute to the existing literature by proffering an integration and empirical results to elaborate the dynamics and causal relationship of facets that de facto and affects multilateral trade flows of these countries, nevertheless, by estimating and examining how the role of institutions affects the course of international trade in the neighboring countries of Ghana (Togo, Burkina Faso, and Cote d'Ivoire).

\section{Institutions, Economic Freedom, and Trade}

An institution as defined by Douglas (1991) is any humanly formulated restraints that structure political, economic and social interactions.

Economic Freedom can be explained as "An aspect of human liberty that is concerned with the material autonomy of the individual in relation to the state and other organized groups. The highest form of economic freedom provides an absolute right of property ownership, fully realized freedoms of movement for labor, capital, and goods, and an absolute absence of coercion or constraint of economic liberty beyond the extent necessary for citizens to protect and maintain liberty itself" (Najaf Ali, 2018). This can be further strengthened to imply that; a transparent institution promotes a conducive economic freedom. The apex of an economic freedom is associated with a resilient economy, perfect interactions of the market forces of demand and supply, human development, healthy environment, higher per capita income or wealth, eradication of poverty, international trade facilitations Ignatius Abasimi (2018).

The smattering research interlinking economic freedom, trade and institutions does not displays a clear spectrograph of the underlining phenomena (see Rose 2000; Acemoglu et al., 2001; Anderson \& Marcouiller 2002; Depken II \& Sonora 2005; Wisdom Akpalu et al, 2017).

\section{Literature Review}

The focused of every government in recent periods is how to increased its economic GDP and perhaps its per capita income of its citizenry. In an itching to accomplished these objectives, several development economists often asked questions such as; What institutional measures promotes innovations and human capital development albeit all the economic turmoil's? (P. Aghion and P. Howitt,1992). why in some societal settings, institutional roles exhibit some positive impacts in technological and innovation advancement, while in some societies they do not? (Parente and Prescott 2005).

Ignatius Abasimi et al (2018) noted in their studies "the impacts of institutions on international trade in Ghana economic perspective" that political and economic institutions exhibit a great and perverse properties on international trade. The study employed the ordinary least square as its econometric tool and the results revealed that business freedom and freedom from corruption has no significant effects on Ghana's trade, however, property rights, monetary freedom, trade freedom and exchange rate exhibit great robust influence on trade in Ghana's economic perspective. Their study empirically refute corruption as an obdurate and a canker that compromise international trade.

A recent study; "role of institutions in affecting the course of international trade in Pakistan" by Najaf Ali (2018), stretched that, institutions like, Trade Freedom, Freedom from Corruption, Property Rights, Monetary Freedom, and Business Freedom, greatly possess some perverse 
effects on Pakistan trade. The study obtains data from the heritage foundation index for the analysis. The results from the multiple linear regression reveals that exchange rate, monetary freedom and some dummy variable has a negative effect on Pakistan trade while other key institutions such as Trade Freedom, Freedom from Corruption, Property Rights, and Business Freedom had a positive relationship with Pakistan trade flows. The study further carried out some diagnostics test (CUSUM stability test and Breusch-Godfrey Serial Correlation LM Test) to determine the variability and perhaps the stability of the parameters considered. The study recommends that, the property rights enforcement agents in Pakistan should be fused along with the business freedom to magnify the prospects of gains from international trade. Nevertheless, exchange rate oscillations should be controlled in order to have stability and long-term trade patterns.

Mohammad D et al (2009) also studied the long run relationship between private investment and government expenditure in Pakistan. The study employed time series data of the Pakistan economy from 1975-2008 period. The Johansen-Juselius co-integration test used in the study shows the existence of long run relationship among the parameters considered. The results refute the existence of short run causality between the studied variables, however, the long run results show that non-government expenditure such as debt service, defense etc. leads to crowding out in private investment sectors and perhaps possess pervasive effects on social and economic development in Pakistan.

Acemoglu et al (2003) shows the effects of institutional quality on economic growth after the world war 2. The results from the two stage least square reveals that institutional mismanagement and oscillations in macroeconomic policies where the major causes of some economic crisis after the war.

David Dollar \& Aart Kraay (2003) in their working paper, "Institutions, Trade, and Growth: Revisiting the Evidence" noted a very crucial interrelationship between Institutions, Trade, and economic Growth. The study employed a mixer of methods (IV regressions, first-stage least square and ordinary least squares) to analyze the interdependence of these economic parameters. The study found out that when institutional quality is used as an exogenous variable, then there is a significant partial association between trade and growth which survives the inclusion of a variety of proxies for institutional quality. Nevertheless, when institutional quality was proxied as an endogenous parameter, they found that the model was relatively weak and unable to estimate the variables in question. Another intriguing finding of the study was that initial income were found to have effects on growth and changes on trade. Conversely, initial institutions once again, predicts the endogenous change in initial income, while initial levels of per capita income that were supposed to be instrumented for the change in initial income were also however, found to explain changes in trade and changes in institutions. The study highlighted in their conclusions that, simple cross-country linear IV regressions, be it or whether at levels or in decadal differences will only result in answering a partial and insignificant portion of the complex interactions roles of institutions and trade on economic growth.

Daniel Kaufmann et al (2004) have noted that a resilient economic development and higher per capita income really depends on the quality of good governance. They further pinpointed in their 2009 report that, they have been a positive robust improvement on voice and accountability by countries such as Ghana, Indonesia, Kenya, Nigeria, and Peru on their governance (institutions) but also declines in that component in countries such as Belarus, Zimbabwe and Venezuela. 
Rohini and Christopher (2005) in their study "Institutions and Development: A View from Below" stressed that institutional development and observed growth in cross-country data possess a robust indications of higher, fast, long-term growth in countries with quality contracting institutions, increased protection of private property rights, improved central government bureaucracy, better law enforcement, increased levels of democracy, higher levels of trust, and smoother operating formal sector financial markets. The study again reveals that index of country openness to trade has apparently reduced poverty to a minimal level in in India, Brazil, and Colombia.

Lant Pritchett (1997), in his paper "divergence, big time" portrays how incomes in the less developing countries has fallen behind those in the developed countries. He again shows how the per capita incomes of these two economists (richest and poorest countries) increased by a factor and the difference only changes by an order of magnitude from 1870 to 1990 . The study further regressed the relative incomes across the 17 countries or nations considered in the study against their GDP per capita and trend ( 1 if $>1960$ and 0 if otherwise). GDP per capita were found to have negative effect on relative incomes of these countries (-0.59), the two-trend considered in his study has coefficients of 0.13 and 0.002 . one intriguing fact about this study is that the author was pretty convinced that the developing countries will be converged to meet the developed countries. The most tantalizing and intuition question behind this study is how does the various institutions interlined to pushed these economies forward? One could probably give a theoretical answer; perhaps, they had well-established institutions.

Weingast \& Milgrom (1990) examined expansion of international trade in the medieval times as in the case of Champaign fair, and noted that trade was made possible largely by private order courts, whereby the judiciary were private and serves as a documentations ground for the records of traders. This exuberated to the habit that the merchants used to ask the private judges regarding the reputation of the trader to which they are going to trade. Private judges caution the merchants to take precautions when conducting business transactions with traders whose credibility is questionable, the judiciary or judges were also expected to impose fines and penalties to the traders for misconduct, and any breach of business contracts and perhaps if a trader would not pay the fines, he or she were to lose all the future possible contracts or opportunities of trade thereafter. Amongst the absence of enforcement of security or property rights and contracts by the State, private judges combined with the private order institutional arrangements, lead traders and merchants to fulfill the contracts.

Wisdom Akpalu et al, (2017) noted in their studies "Evolution of Institutions in Ghana and Implications for Economic Growth" that, GDP growth rate in Ghana was quite intriguing under quality and better institutions and through out her recent two decades of democracy. The econometric method employed in the study was the ordinary least square (OLS) estimations procedure. This was used to determine whether democratic regimes deliver better growth outcomes (GDP growth rates) than the military regimes, it was also employed to empirically verify whether the indicators of the two institutions (Political and civil liberties and Property rights) vary significantly across the three regimes/eras (precolonial, military and democratic regimes). The results show a mixer of relationships. Their studies again revealed that, out of the three formal institutions employed in the study, Civil and Political liberties and Property Rights are better indemnified under democratic regimes, compared to the colonial era and the military regimes. However, the reported indicators of Political instability from the empirical results revealed on the average less favorable outcomes under democratic regimes.

Ahmet Faruk Aysan et al (2006) elongate in their working paper "Governance and Private Investment in the Middle East and North Africa" that structural reforms such as trade openness and financial development, human capital, economic policies and governance institutions 
appears to play a significant role in private investment decisions. The study uses the three stages least squares (3SLS) method or procedure to analyzed a panel of 31 countries from 198020002. The study further reveals that low level of corruption, a good quality of bureaucracy, a clear security of property rights, a reasonable risk to operations, a sound taxation and regulation as well as better law and order are of priorities for entrepreneurs' decisions to invest in these economies. Their study also confirms some of the theoretical literature on economic growth and investment, more specifically, the study confirms the user cost of capital theory and the natural curse hypothesis. However, the model fails to verify the Solow hypothesis of decreasing return to scale of physical capital accumulation. The study concludes that improved governance institutions and economic reforms will create an inducive environment for private investment decisions.

\section{Methodology and Data Sources}

To other to analyze the role of institutions in affecting the course of international trade in the neighboring countries of Ghana, the study employed panel data (1995-2017) which is sourced from the website of the Index of Economic Freedom -Heritage Foundation and world Bank database. The variables applied in the study includes; exchange rate, which is measured as the official exchange rate of 1 unit of the selected countries' currencies per US dollars, total exports of goods and services, freedom from corruption, which is interpreted as the integrity of government institutions in decisions making processes, business freedom, monetary freedom, property rights, which is the extent to which a country's legal framework allows individuals to accumulate private property freely, and trade freedom. The first two variables were obtained from the World Bank development indicators database, whiles the rest of the variables were extracted from the Index of Economic Freedom -Heritage Foundation database.

Panel data technique were adopted because it has advantage over cross-sectional and time series regressions especially when it comes to heterogeneity bias. The results from panel data technique are less spurious and more generalized than the aforementioned methods. Since the data is a panel data, the study employed the mixed effect method model which comprise of the random and the fixed effect technique. Theoretically, the mixed effect model can be express as follows;

For each observation i:

$Y_{i}=\beta_{1} X_{i 1}+\ldots .+\beta_{p} X_{i p}+b_{1} Z_{i 1}+\ldots .+b_{q} Z_{i q}+\varepsilon_{i}$

where $\boldsymbol{\beta}_{\mathbf{1}} \ldots \boldsymbol{\beta}_{\boldsymbol{p}}$ are the unknow parameters of the fixed effects, $\mathbf{X} \mathbf{i}$ are the known regressors or the design variables and $\mathbf{Y i}$ 's are the regressands or observations. Moreover, bi's are the random coefficients and $\mathbf{Z i}$ are the random effect design variables, the $\boldsymbol{\varepsilon} \mathbf{i}$ 's are the error terms which are expected to be independent and normally distributed with zero mean and variances.

The mixed effects model mixes random effects with the fixed effects of a typical regression model. Winter (2013) describes random effects as something that is commonly nonsystematic and impulsive, hence random influence on the data. Fixed effects however, are predictable and systematic.

The standard regression model for the study is given as;

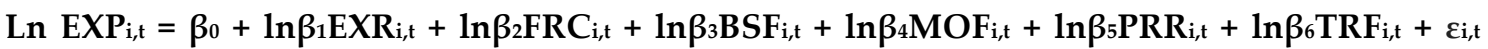

(2)

Where, 
$\beta_{0} \ldots \beta_{6}$ are unknown parameters and constants to be estimated.

EXP represent exports of goods and services,

EXR is exchange rate,

FRC is freedom from corruption,

BSF is business freedom,

MOF is monetary freedom

PRR is property rights

TRF is trade freedom.

$i$ is for country

$t$ is for year

Ln represent natural log.

and $\varepsilon$ is unobserved error term.

\section{Procedure for data analysis}

The study initially performed pooled OLS estimations and on that bases applied the Chow test to ascertained whether the pooled OLS is preferred to the fixed effect or not. The Hausman test was also carried out to investigate whether the fixed effect or the random effect is appropriate for the data. After the preliminary test, the Chow test and the Hausman test refuted pooled OLS and random effects techniques. The fixed effect model therefore was used for the empirical analysis.

\section{Results and Discussion}

Table 1.0 Descriptive statistics

\begin{tabular}{llllll}
\hline Variables & Obs & Mean & Std. Dev. & Min & Max \\
\hline EXR & 69 & $4.39 \mathrm{e}+08$ & $9.45 \mathrm{e}+08$ & 447.8053 & $3.66 \mathrm{e}+09$ \\
TRF & 69 & 23.7942 & 9.076146 & 10 & 38 \\
BSF & 69 & 49.09565 & 8.365043 & 34.8 & 65.4 \\
MOF & 69 & 77.6942 & 5.853176 & 59.1 & 89.4 \\
PRR & 69 & 31.93913 & 5.938464 & 20 & 50 \\
TRF & 69 & 62.37246 & 10.81593 & 12.6 & 76.2 \\
EXP & 69 & $3.76 \mathrm{e}+09$ & $4.22 \mathrm{e}+09$ & $2.51 \mathrm{e}+08$ & $1.37 \mathrm{e}+10$ \\
\hline
\end{tabular}

From table 1.0 above, it's clear that the highest mean is 77.6942 and the smallest is $3.76 \mathrm{e}+09$ which corresponds to monetary freedom and exports respectively. The minimum and maximum values which are $2.51 \mathrm{e}+08$ and 89.4 again, is traced to monetary freedom and exports respectively. We are motivated that; these two variables will have a great impact on trade in the respective countries.

Table 4.2. Correlation matrix

\begin{tabular}{llllllll}
\hline Variables & EXP & BSF & EXR & FRC & MOF & PRR & TRF \\
\hline EXP & 1.0000 & & & & & & \\
BSF & 0.3019 & 1.0000 & & & & & \\
EXR & -0.1469 & 0.1972 & 1.0000 & & & & \\
FRC & 0.0207 & 0.4613 & -0.3002 & 1.0000 & & & \\
MOF & -0.1458 & -0.0576 & -0.2344 & 0.2096 & 1.0000 & & \\
PRR & 0.0301 & 0.3143 & 0.5035 & -0.1427 & -0.3925 & 1.0000 & \\
TRF & -0.5211 & -0.0143 & -0.1360 & 0.1461 & 0.4026 & -0.3004 & 1.0000 \\
\hline
\end{tabular}

The results of the correlation matrix of the role of institutions in affecting the course of international trade in the neighboring countries of Ghana is showed in table 4.2, from the table, trade freedom, monetary freedom and exchange rate has negative correlation with export trade, 
while business freedom, freedom from corruption and property rights has positive correlation with international export trade.

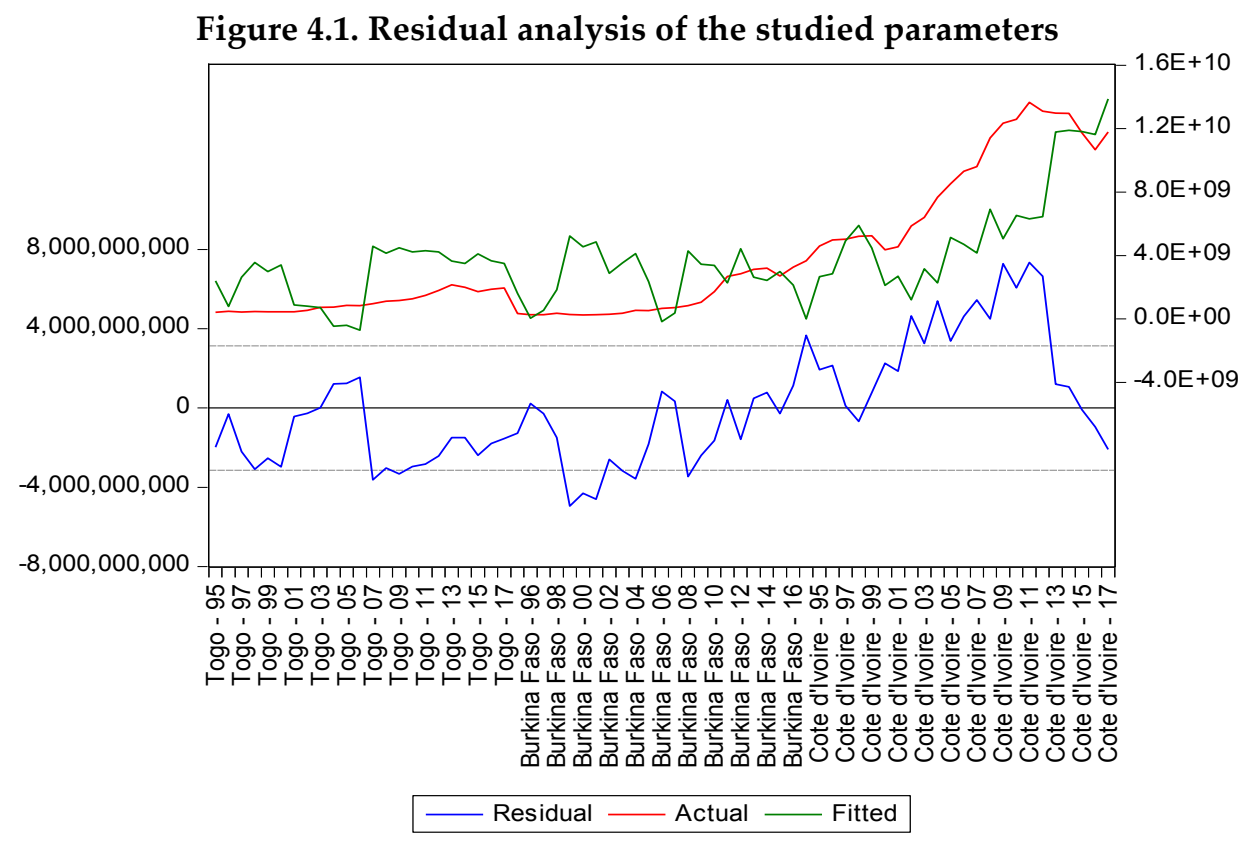

Figures 4.1. Shows the residuals of the variables. This was carried out to ascertained how the data fits the model. The difference between the fitted value and the actual is the residuals. It's worth to note that the residual, actual and the fitted changes in the same direction. The variables therefore have the same properties for the analysis.

Table 4.3 Breusch and Pagan Lagrangian Multiplier Test for Random Effects versus OLS

\begin{tabular}{|c|c|c|}
\hline & Var & $\mathrm{SD}=$ Sqrt (var) \\
\hline EXP & $1.78 \mathrm{e}+19$ & $4.22 \mathrm{e}+09$ \\
\hline $\mathrm{E}$ & $2.38 \mathrm{e}+18$ & $1.54 \mathrm{e}+09$ \\
\hline $\mathrm{U}$ & 0 & 0 \\
\hline Test: $\operatorname{Var}(\mathrm{u})$ & 0 & \\
\hline Chibar $^{2}$ (01) & 0.00 & \\
\hline Prob>chibar ${ }^{2}$ & 1.0000 & \\
\hline
\end{tabular}

Table 4.3 displays the Breusch and Pagan Lagrangian multiplier test for random effects vs pooled OLS technique. The standard deviation and variance of export trade in the studied countries are $4.22 \mathrm{e}+09$ and $1.78 \mathrm{e}+19$ respectively. Based on the p-value, the study rejects the null hypothesis (pooled OLS is better than random effect) and concludes that the random effect is quite efficient.

The study went further to perform Hausman test of random and fixed effect to determine and ascertained which model to use for the empirical results. The results from table 4.4 below shows that the fixed effect model is more efficient than the random effect model largely because, the Pvalue of the $\mathrm{Chi}^{2}<5 \%$. We therefore fail to accept the null hypothesis and conclude that the fixed effect model is effective than random model. 
Table 4.4 Hausman Test for Fixed versus Random Effect Models

DependentVariable Lnexp

\begin{tabular}{llll}
\hline Variables & ------ Coefficients------- & \\
& $(\mathrm{b})$ & $(\mathrm{B})$ & $(\mathrm{b}-\mathrm{B})$ \\
& Fixed & Random & Difference \\
\hline $\operatorname{lnBSF}$ & .4484365 & 4.200792 & -3.752356 \\
$\operatorname{lnEXR}$ & .5554779 & -.0938257 & .6493036 \\
$\ln \mathrm{FRC}$ & -.8486306 & -1.058633 & .2100023 \\
$\operatorname{lnMOF}$ & .2364668 & -.7367713 & .9732381 \\
$\ln \mathrm{PRR}$ & -.3978483 & -1.099708 & .7018598 \\
$\ln \mathrm{TRF}$ & -.7538183 & -1.599996 & .8461781 \\
\hline
\end{tabular}

$\mathrm{b}=$ consistent under Ho and Ha; obtained from xtreg

$\mathrm{B}=$ inconsistent under $\mathrm{Ha}$, efficient under Ho; obtained from xtreg

Test: Ho: difference in coefficients not systematic

chi2 $(6)=(b-B)^{\prime}\left[\left(V_{-} b-V_{-} B\right)^{\wedge}(-1)\right](b-B)=68.1$

$\mathrm{P}>\mathrm{chi} 2=0.0000$

Table 4.5 Fixed Effect Model Estimates

Dependent Variable lnEXP

\begin{tabular}{lllll}
\hline Variables & Coefficient & Standard Error & t-ratio & P-value \\
\hline $\ln B S F$ & .4484365 & .3892516 & 1.15 & 0.254 \\
LnEXR & -.5554779 & .0899488 & 6.18 & $0.000^{* * *}$ \\
LnFRC & .8486306 & .1205688 & 7.04 & $0.000^{* * *}$ \\
LnMOF & .2364668 & .6531337 & 0.36 & 0.719 \\
LnPRR & .7538183 & .2002333 & 3.76 & $0.064^{*}$ \\
$\operatorname{lnTRF}$ & .7538183 & .1964394 & 3.84 & $0.000^{* * *}$ \\
C & 22.89128 & 8.524096 & 2.69 & $0.007^{* * *}$ \\
\hline
\end{tabular}

Note, asterisk ${ }^{* * *},{ }^{*}$ means significance at $1 \%$ and $5 \%$ levels

R-Square $=0.7843, \quad$ F Statistic $(6,60)=36.35$, Prob $>F=0.0000$

Table 4.5 displays the empirical results of the fixed effect model. The outputs from the model reveals that exchange rate, freedom from corruption, property rights and trade freedom are statistically significant in explaining the role of institutions in promoting or affecting the course of international trade in the countries considered. The R-square also depicts the goodness of fit of the model as evidenced with a value of 0.7843 or $78 \%$. This shows that the regressors has been explained by the regressand by $78 \%$.

The results show that a "significant" (not total depreciation) percentage increase in the exchange rate depreciation of the respective countries currencies to the US dollar will lead to an increased in trade (as measured by the export of goods and services) by $56 \%$. Depreciation of the considered country currencies makes the export of goods and services cheaper to the rest of the world, hence promoting trade. The study statistics further reveals that freedom from corruption has a positive and a great impact on international export trade, it has $85 \%$ effect on trade for every percentage increased in freedom of corruption in the respective countries. Property rights has a positive and significant effect on export trade, its increases trade by $75 \%$ for every percentage increased or improvement in property rights. Lastly, is trade freedom. 
Trade freedom also possesses a positive and a significant relationship with trade. It has a coefficient of 0.75 , which implies that a significant percentage increased in trade freedom will increase the volume of trade by $75 \%$.

The findings of this study confirmed with previous studies on institutions and trade (see Ignatius Abasimi et al, 2018, Najaf Ali,2018, Wisdom Akpalu et al, 2017, Rohini and Christopher, 2005, David Dollar \& Aart Kraay, 2003, Ahmet Faruk Aysan et al, 2006). For instance, Ignatius Abasimi et al (2018) found out that property rights, trade freedom, monetary freedom and exchange rates has a robust effect on international trade in Ghana economy. Najaf Ali (2018) studies also confirmed that trade Freedom, freedom from corruption, property rights, monetary freedom, and business freedom greatly possess some perverse and positive effects on Pakistan trade. Ahmet Faruk Aysan et al (2006), concludes that structural reforms such as trade openness, a clear security of property rights, financial development, human capital, economic policies and governance institutions exhibits significant role in private investment decisions.

\section{Conclusion and Recommendation}

An institution is a humanly devised constraints that structure political, economic and social interactions (Douglass Cecil North, 1991). This study combines both political and economic institutions to access their impact on international trade. More specially, the study observed the role of institutions in affecting the course of international trade in the neighboring countries of Ghana; including Togo, Burkina Faso, and Cote d'Ivoire. The empirical results from the econometric analysis reveals quite a robust and significant relationship of parameters such as exchange rate, freedom from corruption, property rights and trade freedom on international trade in the particular countries. One intriguing findings of the study is that all the significant variables except exchange rate are associated with the political institutions in the respective countries. Therefore, its recommended that the government and necessary agencies should conceive and hatch suitable and relevant policies to strengthen the political institutions and all the supplementary sectors in supporting and promoting the course of international export trade. Again, the ministries in charge of trade should be fortified and focused so as to enhanced and maximize the potentials gains from international trade. This will attract and motivate investors who want and have the passion to engage in international transactions to do so with little frustrations. When government impose and implement appropriate policies, it will move along way to boost, intensify and enlarge its economic salvation in the long run.

This study makes a profound contribution to the theoretical and empirical literature in the following direction; from the word go, it's the first study to incorporate and investigates the role of institutions in promoting the course of international trade in the neighboring countries of Ghana. Contextually, the study offers an integration and theoretical characteristics that intricated the dynamics and causal relationship of facets that de facto multilateral trade flows in the studied countries. 


\section{References}

A. Depken II and R. J. Sonora (2005). "Asymmetric effects of economic freedom on international trade flows," Int. J. Bus. Econ., vol. 4, no. 2, p. 141.

Abasimi, I., Li, X., \& Khan, M. I. (2018). The Impacts of Institutions on International Trade in Ghana's Economic Perspective. International Journal of Academic Research in Economics and Management Sciences, 7(4), 32-43.

Acemoglu, D., Johnson, S., and Robinson, J.A., (2001), "The Colonial Origins of Comparative Development: An Empirical Investigation", American Economic Review, 91(5):1369-1401.

Aysan, Ahmet Faruk \& Nabli, Mustapha Kamel \& Veganzones-Varoudakis, Marie-Ange (2006), "Governance and private investment in the Middle East and North Africa", Policy Research Working Paper Series, 3934, The World Bank.

Chong, A., Calderon, C. (2000). Causality and feedback between institutional measures and economic growth. Economics and Politics 12, 69-81.

Daniel Kaufmann Aart Kraay Massimo Mastruzzi (2009). "Aggregate and Individual Governance Indicators for 1996-2008.” World Bank Policy Research Working Paper No. 4978, Washington, D.C

David Dollar and A. Kraay (2003) "Institutions, trade, and growth," Journal of Monetary Economics.

Douglass Cecil North (1991). “Institutions.” Journal of Economic Perspectives 5, no. 1: 97-112.

Easterly, W., Levine, R. and Roodma, D. (2004), "Aid, policies, and growth: comment", American Economic Review, Vol. 94 No. 3, pp. 774-80.

J. E. Anderson and D. Marcouiller (2002). "Insecurity and the Pattern of Trade: An Empirical Investigation," Rev. Econ. Stat., vol.84, no. 2, pp. 342-352.

K. Rose (2000). “One Money, One Market: Estimating the Effect of Common Currencies on Trade," Econ. Policy, vol. 15, no. 30, pp. 7-45.

Kaufmann, Daniel, Aart Kraay and Massimo Mastruzzi (2004). "Governance Matters III: Governance Indicators for 1996, 1998, 2000, and 2002". World Bank Economic Review. 18:253-287.

L. I. Hussain, Adnan, Mohammad D. Sulaiman (2009) "Effectiveness of Government Expenditure Crowding-In or Crowding-Out: Empirical Evidence in Case of Pakistan," Econ. Financ. Adm. Sci., vol. 16, no. 16, p. 7.

Lant. Pritchett (1997). “Divergence, Big Time,” J. Econ. Perspect., vol. 11, no. 3, pp. 3-17.

Law, S. H., Lim, T. C., \& Ismail, N. W. (2013). Institutions and economic development: A Granger causality analysis of panel data evidence. Economic Systems, 37(4), 610-624.

Najaf Ali and Ye Mingque (2018). "Role of institutions in affecting the course of international trade in Pakistan". American Journal of Economics 2018, 8(1): 18-22. DOI: 10.5923/j.economics.20180801.04

P. Aghion and P. Howitt (1992) "A model of growth through creative destruction," Econometrica, vol. 60, no. 2, pp. 323-351.

P. R. Milgrom, D. C. North, and B. R. Weingast (1990) “The Role of Institutions in the Revival of Trade: The Law Merchant, 
P. Rohini and C. Udry (2005) "Institutions and Development: A View from Below," Work. Pap. Yale Sch. Manag. Econ. Res. Netw., pp. 31-61.

Private Judges, and The Champagne Fairs.," Econ. Polit., vol. 2, no. 1, pp. 1-23.

S. L. Parente and E. C. Prescott (2005). A Unified Theory of the Evolution of International Income Levels.

Solow Robert Merton. (1956). "A contribution to the theory of economic growth". Quarterly Journal of Economics. Oxford Journals. 70 (1): 65-94. doi:10.2307/1884513. JSTOR 1884513.

Wikipedia (2018). Retrieved online at https://en.wikipedia.org/wiki/Ordinary_least_squares.

Wisdom Akpalu, George A.Emmanuel M.L. and Mare Sarr (2017). “Evolution of Institutions in Ghana and Implications for Economic Growth". Ersa working paper 710, Ersa economic research southern Africa.

World Bank (2018) Africa report. Retrieved online at https://qz.com/africa/1179387/africaseconomic-outlook-is-promising-for-2018-but-there-clouds-on-the-horizon/. 